Journal of Fish Biology. v. 70, n. 6, 2007, pp. 1838-1854.

Print ISSN: 0022-1112

Online ISSN: 1095-8649

doi:10.1111/j.1095-8649.2007.01459.x,

http://www.blackwell-synergy.com

http://www3.interscience.wiley.com/cgi-bin/fulltext/118483391/PDFSTART

(c) 2007, Blackwell Publishing Ltd.

\title{
Prey resources before spawning influence gonadal investment of female, but not male, white crappie
}

\section{B. Bunnell, S. E. Thomas AND R. A. Stein}

Aquatic Ecology Laboratory, Department of Evolution, Ecology, and Organismal Biology, The Ohio State University

In this study, an outdoor pool experiment was used to evaluate the effect of prey resources during 4 months before spawning on the gonadal investments of male and female white crappie Pomoxis annularis, a popular freshwater sportfish that exhibits erratic recruitment. Fish were assigned one of three feeding treatments: starved, fed once every 5 days (intermediate) or fed daily (high). All measurements of male testes (i.e. wet mass, energy density and spermatocrit) were similar across treatments. Conversely, high-fed females produced larger ovaries than those of intermediate-fed and starved fish, and invested more energy in their ovaries than starved fish. Compared to preexperiment fish, starved and intermediate-fed females appeared to increase their ovary size by relying on liver energy stores ('capital' spawning). Conversely, high-fed females increased liver and gonad mass, implying an 'income'-spawning strategy (where gonads are built from recently acquired energy). Fecundity did not differ among treatments, but high-fed fish built larger eggs than those starved. Females rarely 'skipped' spawning opportunities when prey resources were low, as only $8 \%$ of starved females and $8 \%$ of intermediate-fed females lacked vitellogenic eggs. These results suggest that limited prey resources during the months before spawning can limit ovary production, which, in turn, can limit reproductive success of white crappies.

\section{INTRODUCTION}

In recent years, fish ecologists have gained a better understanding how female phenotypic characteristics are linked to offspring characteristics, i.e. maternal effects (Chambers \& Leggett, 1996; Solemdal, 1997). Generally speaking, prey resources influence maternal size and condition (Bernardo, 1996), which ultimately may influence recruitment success (Marshall et al., 1999). What is less well understood, however, is the temporal linkage between prey resources and reproductive output. For example, for fishes that rely on energy stores to fuel their gonadal growth (i.e. 'capital' spawners), prey resources available in the year (or years) before spawning can influence the ultimate reproductive output. Conversely, for fishes that rely on recently acquired prey resources to fuel gonadal growth (i.e. 'income' spawners), prey resources available weeks or months before spawning can influence reproductive output. These 'capital' and 'income'-spawning strategies represent the extremes of a continuum of reproductive life-history strategies (Bonnet et al., 1998). Indeed, knowing where a particular taxon lies along this continuum can help fish ecologists and managers better understand when prey resources influence the amount or even quality of gonadal growth, which is one of many bottlenecks that can limit the year-class success.

Independent of the energy source (i.e. energy stores or recent prey) for gonadal growth, limited prey resources during a period critical to gonadal growth can have multi-level effects. At a first level, limited prey can induce mature, iteroparous females to 'skip' spawning. Although 
several environmental factors probably contribute to the propensity to 'skip', such as mate availability, water temperatures or water quality, the most common factor is fish nutrition (Rideout et al., 2005). If spawning proceeds, however, the next question is whether the level of gonadal investment will be limited by prey resources. For example, smaller gonads (Lambert \& Dutil, 2000), fewer eggs (Wootton, 1977) or even smaller, presumably low-quality, eggs (Hay et al., 1988) may be produced if prey resources are limited during periods critical to gonadal investment.

Although field studies have documented 'skipped' spawning by mature females (Burton \& Idler, 1984; Holmgren, 2003) and variable gonadal investment across years (Kjesbu et al., 1998; Kraus et al., 2000), controlled laboratory studies offer an ideal opportunity to understand how prey resources influence gonadal, as well as somatic, growth. Experiments with winter flounder Pseudopleuronectes americanus (Walbaum) and plaice Pleuronectes platessa L. revealed that mature iteroparous females appear to skip spawning given limited prey resources 4 to 6 months before spawning (Tyler \& Dunn, 1976; Rijnsdorp, 1990). In all other experiments, however, mature females either built gonads or also spawned eggs, despite limited prey in the months before spawning. In many cases, fishes fed lower rations had lower size-specific fecundity or ovary sizes (Hirshfield, 1980; Ma et al., 1998; Lambert \& Dutil, 2000), spawned fewer eggs (Wootton, 1977; Hislop et al., 1978), and even produced smaller eggs (Hislop et al., 1978; Hay et al., 1988; Fletcher \& Wootton, 1995) than fishes fed higher rations. In other cases, however, the feeding level was unrelated to size-specific fecundity (Hay \& Brett, 1988) or egg size (Scott, 1962; Wootton, 1973; Ma et al., 1998). Finally, a starved feeding treatment is required to assess whether fishes will convert stored energy to gonads which, in turn, will provide insight into whether 'capital' - or 'income'-spawning strategies are used. For example, capital-spawning ability was demonstrated by Pacific herring Clupea pallasii pallasii Valenciennes that were starved for 3 months prior to spawning but yet continued to build ovary tissue throughout starvation (Hay et al., 1988).

Because ovaries require greater energetic investment than testes (Jonsson et al., 1991), most experiments exploring how food resources influence gonadal investment have focused on females. In the few experiments with males, higher rations can lead to higher gonado-somatic indices $\left(I_{\mathrm{G}}\right)$ values and testes mass (Yoneda \& Wright, 2005) although this may not always be the case (Karlsen et al, 1995; Bromley et al, 2000). Because higher $I_{\mathrm{G}}$ can lead to higher sperm count and motility (Gage et al, 1995) although again in some studies no relationship has been found (Evans \& Geffen, 1998) and higher sperm counts can increase fertilization rates (Aas et al, 1991), prey resources available to males could conceivably influence recruitment success as well.

The present laboratory experiment was designed to quantify the multi-level effects of prey resources on the gonadal investment of female and male white crappie Pomoxis annularis Rafinesque, a popular North American freshwater sportfish with high recruitment variability (Beam, 1983; McDonough \& Buchanan, 1991; Bunnell et al, 2006). First, it was determined whether white crappies fed low rations during 4 months before spawning would forego gonadal growth (and presumably 'skip' spawning) to maintain somatic tissue. Second, for those fish that allocated energy to gonads, it was determined whether gonadal investments increased with prey resources. Finally, by including a starved treatment and by measuring the energetic investment in gonadal, somatic and liver tissue, whether white crappies were oriented towards 'income'- or 'capital'-spawning strategies could be explored.

White crappies spawn over a 6-8 week period during spring (Bunnell et al., 2003). Males 
build littoral nests in lakes or reservoirs and then defend incubating eggs and embryos until yolksac absorption (up to 6 days; Siefert, 1968). In 11 Ohio populations for which data have been collected (Bunnell et al., 2006), white crappies mature by age 2 years [c. $185 \mathrm{~mm}$ total length $\left(L_{\mathrm{T}}\right)$ ], but longevity (i.e. oldest fish captured) ranges from 3 to 12 years in age. Because previous studies indicate that year class strength (YCS) is set at the larval stage, if not sooner (Allen \& Miranda, 1998; Sammons \& Bettoli, 1998; Maceina, 2003; Bunnell et al., 2006), it follows that variation in gonadal investment could influence larval production and recruitment success.

\section{MATERIALS AND METHODS}

All methods were approved by The Ohio State University Institutional Laboratory Animal Care and Use Committee under Protocol 00A0135. Adult white crappies were collected with Missouri-style trapnets (Colvin \& Vasey, 1986: $1.3 \mathrm{~cm}$ mesh, with two $0.9 \times 1.8 \mathrm{~m}$ square frames, four $0.8 \mathrm{~m}$ diameter hoops and a $21 \mathrm{~m}$ lead) set over 30 net-nights (10 nets, each net set over three nights) from Pleasant Hill Reservoir, Ohio, U.S.A., during 16-18 October 2001. More than 400 adults were collected; $L_{\mathrm{T}}$ was measured for all and total mass $\left(M_{\mathrm{T}}\right.$, nearest $\left.0.5 \mathrm{~g}\right)$ was measured for up to 10 fish per $\mathrm{cm}$ size class. A sub-sample of 59 white crappies was euthanized with tricaine methanesulphonate (MS-222, $150 \mathrm{mg} \mathrm{l}^{-1}$ ), placed on ice, and then returned to the laboratory to quantify $L_{\mathrm{T}}, M_{\mathrm{T}}$, somatic mass ( $M_{\mathrm{S}}$, all tissue except liver and gonads), age, sex and energy density of gonads, liver and somatic tissue. These fish served as an index of the energetic status of white crappies before the experiment ('pre-experiment' fish). Another sub-sample of 169 adults was transported in aerated, salted $(0.5 \% \mathrm{NaCl}$ by mass, to reduce physiological stress) 6001 tanks back to the Aquatic Ecology Laboratory. Upon arrival, up to 14 fish were placed in each of twelve 30001 circular, outdoor, aerated pools, and fed fathead minnows Pimephales promelas Rafinsque ad libitum until the experiment began on 6 December 2001. Most white crappies did not begin feeding in the pools until early November, which delayed the start of the experiment. Dechlorinated, municipal water flowed through the pools at a rate of 5000-7000 1 day $^{-1}$. One half of each pool was covered with black plastic while the other half was covered with $1 \mathrm{~cm}$ diameter mesh.

Two weeks before beginning the experiment, fish were anaesthetized with MS-222 (30 $\mathrm{mg}^{\mathrm{l}^{-1}}$ ), and then individually measured for $L_{\mathrm{T}}$ and $M_{\mathrm{T}}$, and marked. A hypodermic needle was used to insert a fluorescent elastomer mark (Northwest Marine Technology, Shaw Island, WA, U.S.A.) into the unpigmented anal fin. One of four colours was inserted into one of four positions (right or left side, anterior or posterior position) to uniquely mark each of 14 fish in each of nine pools. No fish died due to marking. Some fish were moved to different pools to ensure similar size distributions among pools. Because sex could not be identified externally, sex ratios within each pool were unknown.

When the experiment began, one of three feeding treatments was randomly assigned to each pool ( $n=3$ pools per treatment): starved, intermediate and high. Fathead minnows (mean \pm S.D. $M_{\mathrm{T}}=1.4 \pm 0.3 \mathrm{~g}, n=100$; energy density $=3765 \pm 884 \mathrm{~J} \mathrm{~g}^{-1}, n=6$ ) purchased from a local bait store were used as prey. Fish in the high-feeding treatment were fed daily, whereas fish in the intermediate treatment were fed every 5 days. By providing a large amount of prey every 5 days to intermediate-fed fish, each fish (regardless of dominance) would have a greater opportunity to eat. This approach differs from a small daily ration approach, in which dominant fish might consume the entire ration designated for the group.

During 1200-1600 hours each day following feeding, dead and remaining fathead minnows were counted to calculate numbers consumed. In the intermediate treatment, the 
remaining fathead minnows were removed. For intermediate and high treatments, daily feeding ration was a function of water temperature $(T)$ and initial adult white crappie biomass ( $B$, sum of $M_{\mathrm{T}}$ in each pool). $T$ was recorded six times per day by remote loggers and once per day by the fish feeder. For each day of feeding, the total biomass of fathead minnows to feed per pool $(D)$, in g, equalled: $D=(f(T) 0.038) B$, where $f(T)$ is the temperature dependence function from the white crappie bioenergetics model $\left[f(T)=V^{1.87} \mathrm{e}^{1.87(1-V)}\right.$, where $V=(32-T) 8^{-1} ;$ Zweifel, 2000], 0.038 is the mass-standardized, maximum daily consumption rate $\left(g_{\text {prey }} g_{\text {fish }}{ }^{-1}\right.$ days $\left.{ }^{-1}\right)$ for white crappie at optimal $T$ ( $24^{\circ} \mathrm{C}$; Hayward \& Arnold, 1996). To calculate $T$ for the intermediate treatment, mean $T$ for the preceding 5 days was calculated. $D$ was then divided by $1.4 \mathrm{~g}$ to estimate the number of fathead minnows to provide for each feeding; this number was adjusted for the number of remaining fathead minnows in the high-feeding treatment. When $T \leq 5^{\circ} \mathrm{C}$, the prey biomass always equalled less than one fathead minnow per fish. When this occurred, the ration was increased to one fathead minnow per fish to raise the probability that each fish had the opportunity to eat.

The experiment ended on 15 April 2002 because $T$ had warmed to nearly $16^{\circ} \mathrm{C}$, the point at white crappies begin spawning (Siefert, 1968). Fish were euthanized with MS-222 (150 mg $1^{-}$ $\left.{ }^{1}\right)$. Each fish was identified according to its unique fluorescent elastomer mark, dissected to determine sex and measured for $M_{\mathrm{T}}$ (nearest $0.1 \mathrm{~g}$ ) and $L_{\mathrm{T}}$. Gonads, liver and stomach and intestinal contents were then removed from all fish. Gonads, liver and $M_{\mathrm{S}}$ were weighed separately. Remaining $M_{\mathrm{S}}$ was placed in a labelled bag filled with water and stored at $-20^{\circ} \mathrm{C}$ for later estimation of $\%$ dry mass $\left(\% M_{\mathrm{D}}\right)$ from $\% M_{\mathrm{D}}=\left(100\left(M_{\text {dry }}\right)\left(M_{\text {wet }}\right)^{-1}\right)$ and energy density.

To determine relative energy allocation, energy density of gonads, liver and somatic tissue (defined as all remaining tissue after the gonads and liver were removed) was estimated for all fish, either directly through bomb calorimetry or indirectly through a predictive relationship between $\% M_{\mathrm{D}}$ and energy density $\left(\mathrm{kJ} M_{\text {wet }}{ }^{-1}\right)$. Energy density was estimated on a sub-set of fish chosen to span the $\% M_{\mathrm{D}}$ range of the experimental fish. Briefly, each tissue was dried to a constant mass at $65-70^{\circ} \mathrm{C}$ and then homogenized into powder with either mortar and pestle (gonads and liver) or a Retsch ZM 100 electric tissue grinder (somatic tissue) and then redried for 3 days at $65-70^{\circ} \mathrm{C}$ (Bunnell et al., 2005). Oxygen calorimeters that could handle both small (0.2 g, Parr Instruments, Moline, IL, U.S.A., Model 1425) and large tissue samples (1.0 g, Parr Model 1341) were used. Energy density of each tissue equalled the mean of at least two composite pellets, each corrected for liberated $\mathrm{H}_{2} \mathrm{SO}_{4}$ (using a base titration), sulphur content (using a fixed average) and fuse combustion (Parr Instrument Co., 1993). To generate regression models, energy density and $\% M_{\mathrm{D}}$ were measured from 20 livers, 10 testes, 21 ovaries and 11 somatic tissues.

To estimate ovary energy density and fecundity from the same female, the ovary lobes were bisected with the right lobe being used for fecundity and the left one being used for $\% M_{\mathrm{D}}$ and energy density. Using white crappies collected from Pleasant Hill Reservoir, as well as other Ohio reservoirs, neither energy density (paired $t$-test, $P>0.05, n=8$ white crappies; D. B. Bunnell, unpubl. data) nor fecundity (paired $t$-test, $P>0.05, n=109$ white crappies; D. B. Bunnell, unpubl. data) differed between the two lobes. To estimate fecundity, the right lobe was weighed (nearest $0.01 \mathrm{~g}$ ) and then preserved in 5\% buffered formalin (Bunnell et al., 2005). Briefly, vitellogenic (i.e. fully yolked, 0.40-1.0 mm diameter) eggs in each of three $4 \mathrm{~mm}$ diameter cores were counted. The diameter of the first 50 vitellogenic eggs encountered in each core was also measured. After counting and measuring, the individual cores and the remaining ovary were dried at $60^{\circ} \mathrm{C}$ to a constant mass. Mean egg density (number of eggs per core dry 
mass) of the three cores was then multiplied by the total dry mass of the right lobe (remaining ovary plus three cores) to estimate the right lobe fecundity for each fish. Fecundity was estimated from only a sub-set of fish, and within a treatment, the sub-set was chosen to be similar to the size distribution of all experimental fish within each treatment. Because the number of fish processed for fecundity was equal across pools $(n=4), 12$ females were selected from each treatment.

From male gonads, sperm density, motility, as well as energy density were evaluated. Spermatocrit, the percentage of sperm cells in the semen, was used as a measure of sperm density, owing to their high correlation (Aas et al., 1991). Plain mylar wrapped haematocrit tubes (two to three tubes per testes) were used to pierce the testes and to initiate flow of milt into each tube. Once collected, tubes were sealed and spun for $10 \mathrm{~min}$ in a haematocrit centrifuge. The height of the sperm cells (nearest $0.1 \mathrm{~cm}$ ) and the total height of the semen (nearest $0.1 \mathrm{~cm}$ ) were measured for each tube, and spermatocrit was calculated as a percentage of semen. Spermatocrit values for each tube were averaged for a final spermatocrit value for each fish. Motility was assessed by placing one to two drops of milt along with a drop of pool water on a microscope slide, and then assessing movement (or not) at $\times 40$ magnification.

Mixed models in SAS (SAS Institute Version 9.1, Cary, NC, U.S.A.) were used to analyse the effects of feeding treatments on somatic, liver and gonadal tissue, because they account for the multi-level structure of the data (individual fish nested within one of three pools for a given treatment) as well as for the random effect of pool. White crappies sampled in October from Pleasant Hill Reservoir (i.e. pre-experiment fish) were also included in the analysis to determine whether a response variable (i.e. somatic, liver or gonadal tissue measurements) had changed from the previous autumn to the end of the experiment. Where applicable, these preexperiment fish were treated as a fourth treatment and each was assigned to the same 'pool'. When $M_{\mathrm{S}}$ or total somatic energy density (i.e. somatic energy density $\times M_{\mathrm{S}}$ ) was the response variable, the 1n transformation of both the response variables as well as their covariate, $L_{\mathrm{T}}$, were used because mass exponentially increases with length. When liver or gonadal tissue was the response variable, no transformations were necessary but $M_{\mathrm{S}}$ was used as a covariate. All mixed models also included a treatment $\times$ covariate interaction term. In each mixed model, treatment and pool were set as class variables, and pool, nested within treatment, was set as a random effect. Least-squares means were calculated for each treatment, and Tukey-Kramer adjustments were used for multiple comparisons. A mixed model, rather than a general linear model (GLM), was used because the mixed procedure computes the S.E. of least-squares mean correctly (Littell et al., 1998; Wagner et al., 2006).

\section{RESULTS}

\section{RELATIONSHIP BETWEEN PER CENT DRY MASS AND ENERGY DENSITY}

For experimental fish, predictive relationships between $\% M_{\mathrm{D}}$ and energy density were developed for somatic, liver and gonadal tissues. Because ANCOVA found neither sex nor the interaction between sex and $\% M_{\mathrm{D}}$ to explain variation in somatic and liver energy density (both $P>0.05$ ), sexes were pooled to provide predictive relationships for these tissues. Both were highly predictive $\left(r^{2}>0.95\right.$, Table I). With regard to gonadal tissue, energy density of both testes and ovaries were strongly related to $\% M_{\mathrm{D}}$ as well $\left(r^{2}=0.96\right.$ and 0.99 , respectively, Table I). In subsequent analyses, calorimetry-derived estimates of energy density were used where available; otherwise, energy density estimates that were predicted as a function of $\% M_{\mathrm{D}}$ were used. 
Because of the wide range of $\% M_{\mathrm{D}}$ used to generate each regression (Table I), extrapolation beyond the data occurred only $5 \%$ of the time. All estimates of energy density from preexperiment white crappies were derived from bomb calorimetry.

\section{EXPERIMENTAL RESULTS}

All white crappies survived the experiment. Initial $M_{\mathrm{T}}$ of fish did not differ across treatments (adjusted $P>0.05$; Table II). In addition, despite the percentage of females varying 43-79\% (Table II), sex ratio did not differ across treatments (one-way ANOVA, $F_{2,6}, P>0.05$ ). Temperatures were generally similar within and across treatments [Fig. 1(a)-(c)], with the exception of pool 7 in the high treatment, which was much more variable and generally warmer than most other pools [Fig. 1(a)]. This variation did not appear to influence consumption, however, as fish in pool $7 \mathrm{fed}$ at a similar rate to fish in the other high treatment pools (Table II) [Fig. 1(d)]. In fact, total consumption varied little within treatments. Consumption in the high treatment was nearly three times greater than in the intermediate treatment (Table II). Intermediate-fed fish, however, generally ate more on a feeding day than did high-fed fish [Fig. 1 (d), (e)]. In addition, intermediate-fed fish consumed all prey during $89 \%$ of feeding events (25 out of 28 for all pools), whereas high-fed fish were generally satiated consuming all prey during only five of 138 feeding events.

Per cent change from initial $M_{\mathrm{T}}$ varied $\left(F_{2,6}, P<0.001\right)$ across treatments, with high-fed fish gaining $11.1 \%$, intermediate-fed fish losing $2.8 \%$ and starved fish losing $10.0 \%$. For comparisons with $M_{\mathrm{S}}$ (i.e. $M_{\mathrm{T}}$ minus liver and gonad masses), pre-experiment fish (sampled from Pleasant Hill Reservoir in October) were included. Among females, high-fed fish had a greater $M_{\mathrm{S}}$ than starved ones (adjusted Tukey-Kramer $P<0.05$ ). No other comparisons revealed differences, including any comparisons with pre-experiment fish. This result suggests that female $M_{\mathrm{S}}$ was unchanged from October (before the experiment) to the end of the experiment in all treatments. Among males, high-fed fish had a greater $M_{\mathrm{S}}$ than pre-experiment fish (adjusted Tukey-Kramer $P<0.01$ ), intermediate-fed fish (adjusted Tukey-Kramer $P<0.01$ ), and starved fish (adjusted Tukey-Kramer $P<0.001$ ). In addition, starved males had a lower $M_{\mathrm{S}}$ than preexperiment males (adjusted Tukey-Kramer $P<0.05$ ).

Energy density of $M_{\mathrm{S}}$ was generally insensitive to feeding conditions. Somatic energy density was similar across the three feeding treatments and the pre-experiment fish for both sexes (adjusted Tukey-Kramer both $P>0.05$ ). Because of the changes in $M_{\mathrm{S}}$ across treatments, however, total somatic energy generally declined in the face of poor feeding conditions, especially in males.

High-fed fish generally increased their liver mass and total liver energy compared to preexperiment, intermediate-fed and starved fish (Fig. 2). The only exception was for males, where total liver energy did not differ between pre-experiment and high-fed fish (adjusted TukeyKramer $P>0.05)$. Intermediate-fed and starved males and females maintained liver size from the preceding autumn (adjusted Tukey-Kramer $P>0.05$ ) [Fig. 2 (a), (d)]. Liver energy density did not change from pre-experiment fish to high-fed males and females (adjusted Tukey-Kramer $P>$ 0.05) [Fig. 2 (b), (e)], but declined from pre-experiment fish to intermediate-fed females and to starved males and females (adjusted Tukey-Kramer $P<0.05$ ) [Fig. 2 (b), (e)]. Overall, high-fed fish increased their liver mass and total liver energy relative to fish sampled during the previous autumn, whereas intermediate-fed and starved fish were largely unchanged from pre-experiment fish. Starved males and females and intermediate-fed females, however, did lose liver energy 
density between autumn and the end of the experiment.

TABLE I. Results of linear regression to predict energy density ( $\mathrm{kJ} M_{\text {wet }}{ }^{-1}$ ) of different white crappie tissues, collected from Pleasant Hill Reservoir, Ohio, U.S.A., as a function of per cent dry mass $\left(\% M_{\mathrm{D}}\right)$.

\begin{tabular}{lcccccc}
\hline Tissue & Intercept & Slope & $F$ & $r^{2}$ & $n$ & $\% M_{\mathrm{D}}$ range \\
\hline Soma (male and female) & $-2 \cdot 36$ & $0 \cdot 28$ & $72 \cdot 3$ & 0.95 & 11 & $22 \cdot 7-27 \cdot 7$ \\
Liver (male and female) & 0.03 & 0.22 & $938 \cdot 8$ & 0.98 & 20 & $10 \cdot 7-32 \cdot 5$ \\
Testes & -0.48 & 0.25 & $220 \cdot 0$ & 0.96 & 10 & $11 \cdot 2-16 \cdot 8$ \\
Ovary & -1.96 & 0.32 & 1658.9 & 0.99 & 21 & $20 \cdot 6-30 \cdot 5$ \\
\hline
\end{tabular}

TABLE II. Summary of mean white crappie $(n=14)$ characteristics in each experimental pool. Experimental white crappies were collected from Pleasant Hill Reservoir, Ohio, U.S.A. Initial biomass was calculated at the beginning of the experiment. Total consumption was measured during the experiment. Mean total length $\left(L_{\mathrm{T}}\right)$ and sex ratio was measured at the end of the experiment. Ninety-five per cent CI are provided in parentheses below each mean estimate.

\begin{tabular}{llccccc}
\hline Pool & $\begin{array}{c}\text { Feeding } \\
\text { treatment }\end{array}$ & $\begin{array}{c}\text { Mean } \\
L_{\mathrm{T}}(\mathrm{mm})\end{array}$ & $\begin{array}{c}\text { Initial } \\
\text { biomass }(\mathrm{g})\end{array}$ & $\begin{array}{c}\text { Sex ratio } \\
(\% \text { female })\end{array}$ & $\begin{array}{c}\text { Total } \\
\text { consumption }(\mathrm{g})\end{array}$ & $\begin{array}{c}\text { Change } \\
\text { in } M_{\mathrm{T}}(\%)\end{array}$ \\
\hline 1 & Starved & $235 \cdot 4(222 \cdot 5,248 \cdot 2)$ & 2550 & 50 & 0 & $-10 \cdot 2(-11 \cdot 2,-9 \cdot 1)$ \\
2 & Starved & $228 \cdot 9(213 \cdot 7,244 \cdot 2)$ & 2452 & 43 & 0 & $-8 \cdot 0(-9 \cdot 0,-6 \cdot 9)$ \\
3 & Starved & $217 \cdot 4(210 \cdot 7,224 \cdot 1)$ & 1997 & 64 & 0 & $-11 \cdot 9(-13 \cdot 5,-10 \cdot 3)$ \\
4 & Intermediate & $226 \cdot 9(219 \cdot 6,234 \cdot 3)$ & 2369 & 43 & 598 & $-4 \cdot 0(-6 \cdot 7,-1 \cdot 2)$ \\
5 & Intermediate & $232 \cdot 6(220 \cdot 0,245 \cdot 3)$ & 2520 & 79 & 609 & $-1 \cdot 7(-4 \cdot 6,1 \cdot 1)$ \\
6 & Intermediate & $228 \cdot 8(220 \cdot 2,237 \cdot 4)$ & 2354 & 57 & 591 & $-2 \cdot 7(-5 \cdot 1,-0 \cdot 4)$ \\
7 & High & $227 \cdot 1(215 \cdot 6,238 \cdot 5)$ & 2270 & 50 & 1674 & $11 \cdot 9(9 \cdot 8,14 \cdot 0)$ \\
8 & High & $226 \cdot 8(219 \cdot 9,233 \cdot 7)$ & 2308 & 57 & 1511 & $9 \cdot 0(7 \cdot 4,10 \cdot 6)$ \\
9 & High & $226 \cdot 2(214 \cdot 9,237 \cdot 6)$ & 2346 & 43 & 1702 & $12 \cdot 4(9 \cdot 9,15 \cdot 0)$ \\
\hline
\end{tabular}

$M_{\mathrm{T}}$, total mass.

Gonadal response differed between females and males. Females in all feeding treatments had a larger ovary mass at the end of the experiment than pre-experiment fish (adjusted TukeyKramer $P<0.05$ ) [Fig. 3(a)]. High-fed fish also had larger ovaries than intermediate-fed and starved fish (adjusted Tukey-Kramer $P<0.05$ ). Ovary energy density did not differ among the three treatments [Fig. 3(b)]. Intermediate-fed and starved fish, however, had a lower ovary energy density than pre-experiment fish (adjusted Tukey-Kramer $P \leq 0.05$ ). With regard to total ovary energy, high-fed fish invested more energy than fish in the starved treatment (adjusted Tukey-Kramer $P=0.05$ ) [Fig. 3(c)], but no other pair-wise comparison yielded significant differences (although adjusted Tukey-Kramer $P=0.06$ for comparisons between high and intermediate and between high and pre-experiment). In summary, females in all experimental treatments increased their wet ovary mass relative to October, with females in the high-feeding treatment adding the most mass. In addition, only high-fed females maintained an energy density similar to pre-experiment fish.

Among a sub-set of 36 experimental fish, fecundity (in the right lobe) and egg diameter increased linearly with $M_{\mathrm{S}}$ (Fig. 4). Fecundity did not differ among treatments, however; only 
high-fed fish nearly differed from starved ones (adjusted Tukey-Kramer $P=0.08$ ). Fecundity was zero in one $230 \mathrm{~mm} L_{\mathrm{T}}$, intermediate-fed fish, and one $247 \mathrm{~mm} L_{\mathrm{T}}$ starved fish. The starved female had the lowest liver energy density of all starved females, which suggests a cause for her failure to initiate vitellogenesis. The intermediate-fed female, however, had average liver and somatic energy densities compared to others in her treatment. High-fed fish produced larger egg diameters than starved fish (adjusted Tukey-Kramer $P<0.05$ ); no other comparisons were significant.

For male gonads, no differences occurred among treatment fish. Testes energy density and total energy, however, declined from pre-experiment to the end of the experiment [Fig. 2(f); adjusted Tukey-Kramer $P<0.01]$. Testes mass was unchanged between pre-experiment fish and those in the three treatments [Fig 2(d); adjusted Tukey-Kramer $P>0.05$ ]. Per cent spermatocrit (a surrogate for sperm density) did not differ across the three treatments either (adjusted TukeyKramer $P>0.17)$. Finally, sperm from all treatments were motile. Thus, testes measurements did not differ across treatments, even though energetic investment declined from October through the end of the experiment.
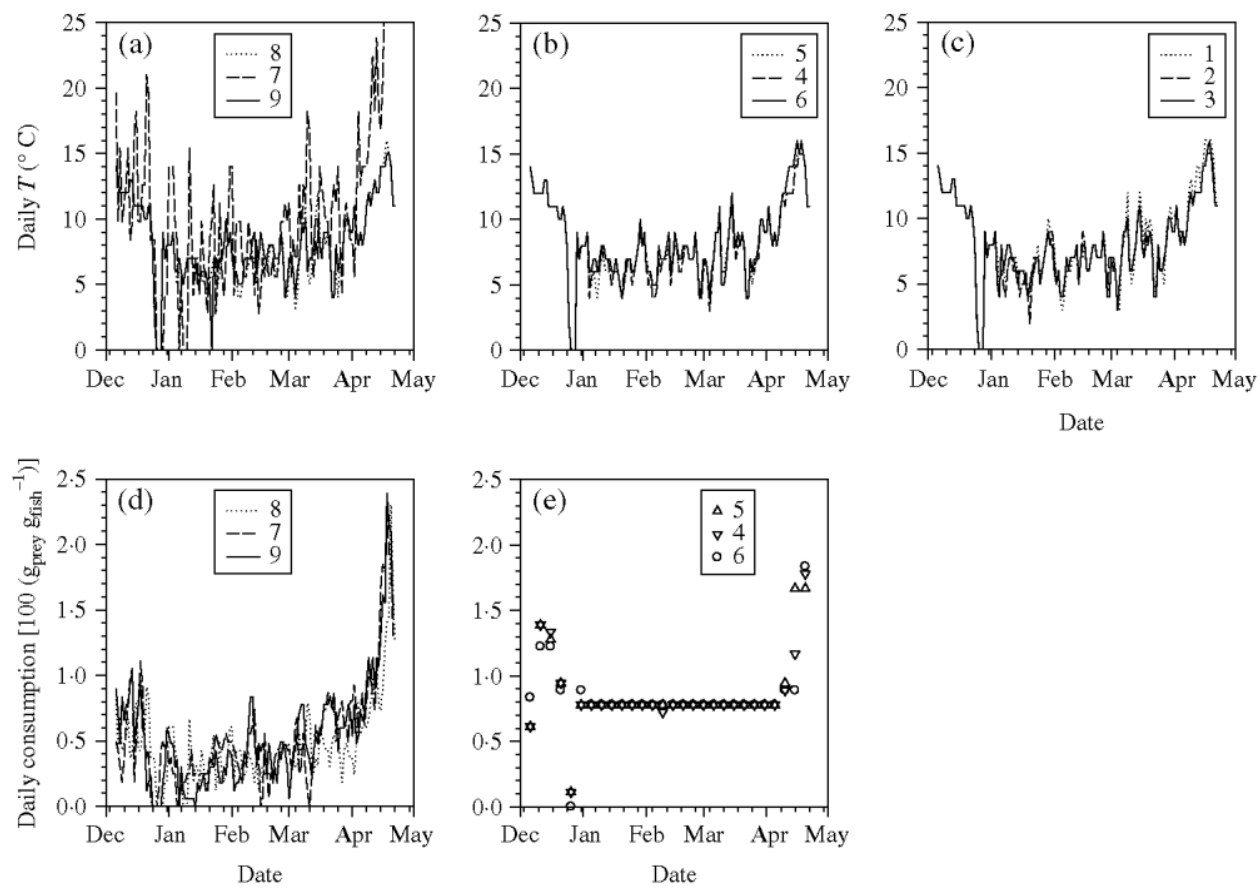

FIG. 1. (a), (b), (c) Mean daily water temperatures $(T)$ and (d), (e) per cent daily consumption for experimental white crappies: (a), (d) high and (b), (e) intermediate treatment and (c) starved fish. Pool numbers are noted in each legend (see Table II). Fish in the high treatment were fed daily and fish in the intermediate treatment were fed every 5 days.

\section{DISCUSSION}

Female, but not male, white crappies increased their gonadal investment as prey increased during the 4 months preceding spawning. Across treatments, males had similar testes mass, energetic investment in testes and spermatocrit levels. Conversely, high-fed females built larger ovaries than intermediate-fed and starved ones, and invested more energy in their ovaries 
than their starved counterparts. At the end of the experiment, intermediate-fed and starved females, however, still had larger ovaries than pre-experiment fish collected in the field during October. These intermediate-fed and starved fish appeared to rely on energy stores in the liver to build their ovaries, as liver energy density was greater in pre-experiment fish than in starved- or intermediate-fed fish. Fecundity did not differ among treatments, but high-fed fish built larger eggs than starved ones. Overall, females rarely 'skipped' spawning opportunities when prey resources were low, as only one of 12 starved females and one of 12 intermediate-fed females failed to initiate vitellogenesis.
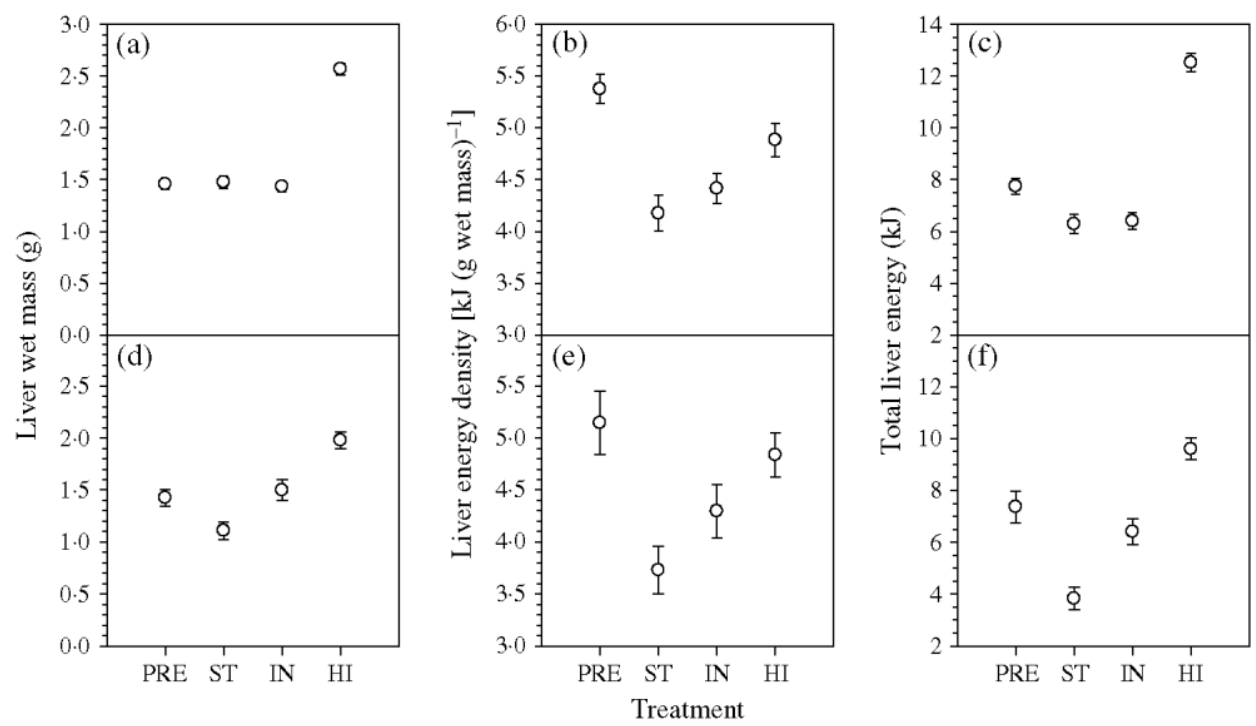

FIG. 2. Least squares mean \pm S.E. (a), (d) wet mass, (b), (e) energy density and (c), (f) total energy of liver tissue estimated from (a) to (c) female and (d) to (f) male white crappies. Fish were either pre-experiment (PRE, sampled 16-18 October 2001, from the same reservoir population as experimental fish) or exposed to one of three feeding treatments: starved (ST, from 6 December 2001 to 15 April 2002), intermediate (IN, fed every 5 days from 6 December 2001 to 15 April 2002) and high (HI, fed daily from 6 December 2001 to 15 April 2002).

'Skipped' spawning opportunities are best documented in female iteroparous fishes, although it can also occur in males (Rideout et al., 2000). In females, 'skipped' spawning can occur in one of three ways (Rideout et al., 2005). First, before spawning, females can fail to start vitellogenesis or begin resorption of vitellogenic eggs, probably owing to sub-optimal $T$ or poor nutrition. Second, during spawning, females could retain ripe eggs owing to high fish densities, too few males or poor water quality. The present experiment tested only poor nutrition, and demonstrated that $92 \%$ of female white crappies initiated vitellogenesis in spite of being starved or being food-limited (as in the intermediate treatment). Some studies with other taxa that have limited food before spawning have found all females to undergo vitellogenesis, independent of level of feeding (Ma et al., 1998; Lambert \& Dutil, 2000). Other studies, however, documented failure to initiate vitellogenesis in food-limited fishes: 25-36\% of turbot Scophthalmus maximus (L.) (Bromley et al., 2000), and 100\% of winter flounder (Tyler \& Dunn, 1976).

Two caveats to the present experiment should be identified. First, it was assumed that females in all treatments were at similar stages of gonadal maturation when the experiment was 
ended. It is possible, however, that females from different treatments also differed in their stage of gonadal maturation. In this situation, it could be concluded that prey resources prior to spawning could affect the timing of spawning as well. Hence, future experiments should have sufficient numbers of animals such that samples could be taken over the course of the experiment so that the effect of ration on timing could be distinguished from the effect of ration on total gonadal investment. Second, histology would be the ideal technique to identify vitellogenic eggs (or reabsorption). Rather, the criterion for vitellogenic eggs in the present study was whether or not ova were fully yolked under magnification. Nonetheless, this is one of several studies that have used 'macro' techniques to assess egg status (Rideout et al., 2005). Of the sub-set of white crappie females for which fecundity was estimated, $8 \%$ of starved and $8 \%$ of intermediate-fed females lacked vitellogenic eggs. Across all treatments, $6 \%$ of females failed to build vitellogenic eggs. These rates are quite comparable to estimates from white crappies sampled in the field. During April (c. 1 to 2 weeks before spawning) 1999-2000 in seven reservoir populations (including Pleasant Hill Reservoir), fecundity was estimated from 127 females, with $L_{\mathrm{T}}$ ranging 166-375 mm (Bunnell et al., 2005; D. B. Bunnell, unpubl. data). Nine per cent (184$230 \mathrm{~mm} L_{\mathrm{T}}$ ) lacked vitellogenic eggs.
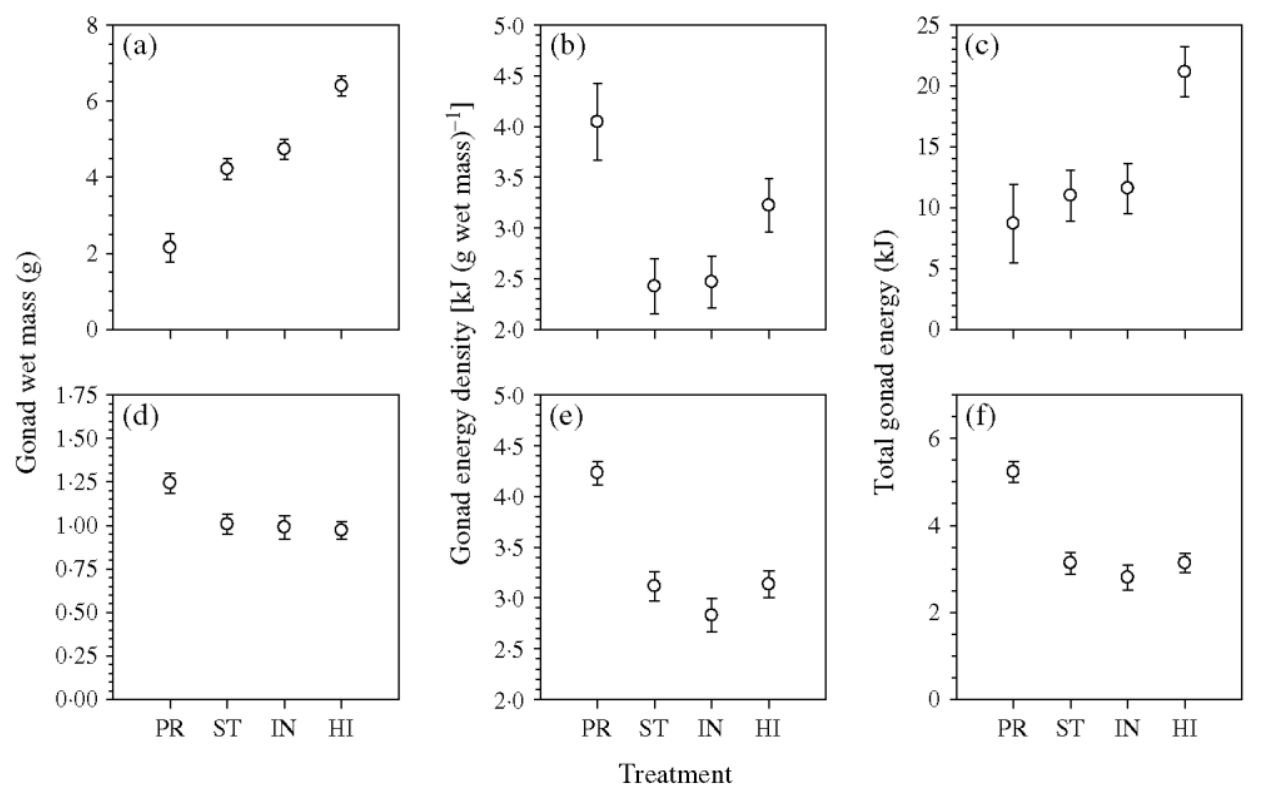

FIG. 3. Least squares mean \pm S.E. (a), (d) wet mass, (b), (e) energy density and (c), (f) total energy of gonad tissue estimated from (a) to (c) female and (d) to (f) male white crappies. Fish were either pre-experiment (PR, sampled 16-18 October 2001, from the same reservoir population as experimental fish) or exposed to one of three feeding treatments: starved (ST, from 6 December 2001 to 15 April 2002), intermediate (IN, fed every 5 days from 6 December 2001 to 15 April 2002) and high (HI, fed daily from 6 December 2001 to 15 April 2002).

Life-history theory predicts that annual mortality will influence the decision of whether to reproduce during the current opportunity (with potentially high energetic costs to somatic and liver tissue) or to wait until next year when conditions may improve (Roff, 1992). Fishes facing high annual mortality probably will favour current reproduction because opportunities for future reproductive events are limited, whereas fishes with low annual mortality probably will favour 
future reproductive opportunities should current conditions be sub-optimal (Roff, 1992; Rideout et al., 2005; Jørgensen et al., 2006). Given the relatively young age at maturity (age 2 years) and generally short longevity (maximum age $=5$ years) of white crappies in Pleasant Hill Reservoir, it is not surprising that $<10 \%$ of females appeared to 'skip' spawning.

Even if most females appear to commit to spawning despite low prey resources, ovary mass and energy increased with frequency of feeding in the present experiment, a result consistent with other taxa (Tyler \& Dunn, 1976; Wootton, 1977; Lambert \& Dutil, 2000). One exception, however, is a study with Pacific herring where higher $I_{\mathrm{G}}$ values occurred in unfed fish than fed fish (Hay et al., 1988). In Pacific herring, vitellogenesis begins in early summer, probably setting a theoretical maximum fecundity by late summer. By not starting their experiment until January, well after vitellogenesis may have been completed, Hay et al. (1988) simply documented the ovary mass set before the experiment; $I_{\mathrm{G}}$ was higher in starved fish because they had a lower $M_{\mathrm{S}}$ than fed fish. In all the other studies, including the present one, critical vitellogenesis overlapped with the timing of the experiment, which presented the opportunity for current feeding conditions to influence gonadal investment.

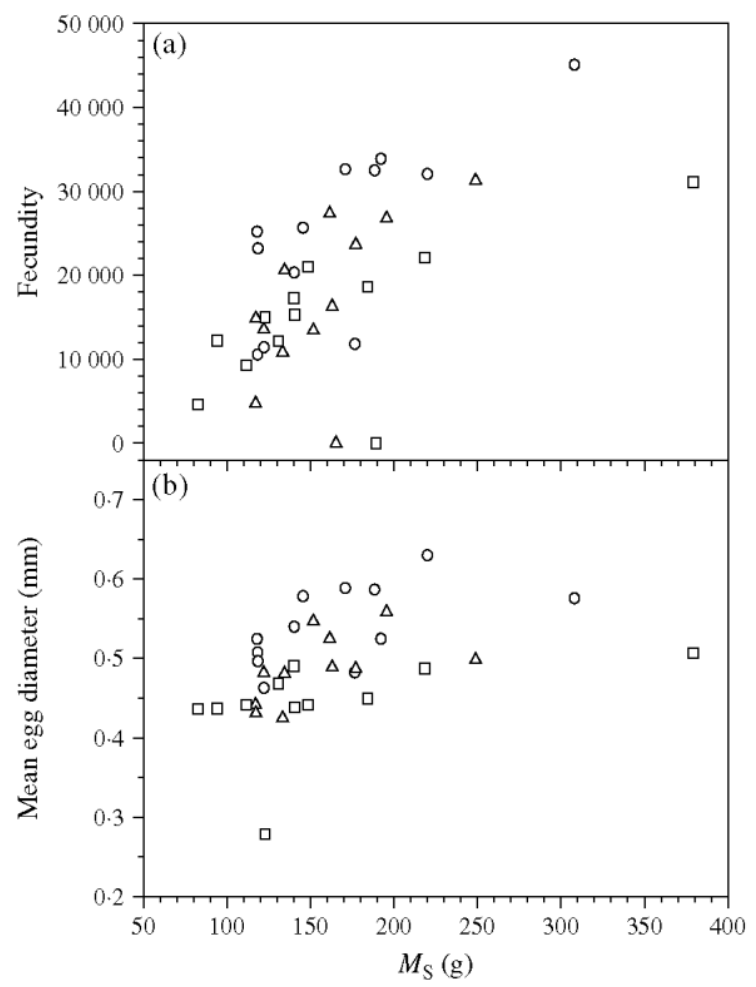

FIG. 4. (a) Fecundity and (b) mean egg diameter from the right lobe of 36 white crappie ovaries as a function of somatic mass $\left(M_{\mathrm{S}}\right)$ exposed to one of three feeding treatments between 6 December 2001 and 15 April 2002: high ( $\circ$, fed daily), intermediate ( $\Delta$, fed every 5 days), and starved ( $\square$ ).

Despite high-fed females growing larger ovaries than both intermediate-fed and starved females, fecundity did not differ. Generally, fecundity has been found to increase with ration (Hirshfield, 1980; Ma et al., 1998; Lambert \& Dutil, 2000), except for the Pacific herring 
experiment (Hay \& Brett, 1988). High-fed females, however, had larger egg diameters than lowfed ones, a result consistent with many experiments (Hislop et al., 1978; Hay et al., 1988; Fletcher \& Wootton, 1995). Hence high-fed females may produce larger ovaries because of larger eggs rather than more eggs. Alternatively, high-fed females may produce larger ovaries than low-fed ones by producing both larger eggs and more eggs. Overall, high-fed females produced larger eggs and probably more eggs (even though the experiment revealed a nonsignificant $P=0.08$ ) than starved females.

By including a starved treatment, the experiment could evaluate whether white crappie build gonads from energy stores (i.e. 'capital' spawners) or from recently acquired food (i.e. 'income' spawners). Starved Pacific herring, for example, increased gonadal tissue while being starved (Hay et al., 1988), suggesting 'capital'-spawning ability. Indeed, most ectothermic vertebrates orient towards 'capital' spawning, primarily because of their ability to store energy with a relatively low energetic cost (Bonnet et al., 1998). Conversely, most endothermic animals are 'income' spawners (Jonsson, 1997), probably owing to their relatively high cost of storing energy. Thus, 'capital' spawners can acquire and store resources during times of high prey, and then can reproduce during times of potentially low prey.

The present experiment provided support for both 'capital'- and 'income'-spawning by female white crappies. Optimality models predict that white crappies should begin gonadal growth up to 6 months before spawning because of uncertainty in prey availability during winter and spring leading up to spawning (Bunnell \& Marschall, 2003). As an extension, it follows that females have evolved at least the capability to be facultative 'capital' spawners because of these potentially limiting resources before spawning. The experiment also suggested that starved and intermediate-fed females were indeed more 'capital'-oriented. Compared to pre-experiment fish, their ovary mass increased and they appeared to transfer energy stores from the liver to gonads, given their liver energy densities were lower than pre-experiment fish. This situation assumes that gonadal growth did not occur during the 40 or so days that females were acclimating to the pools (e.g. learning to eat fathead minnows) before the experiment began. As a result, it cannot be conclusively known if white crappie exhibited full 'capital'-spawning behaviour because fish were not sampled at the beginning of the experiment. In contrast to the other treatments, high-fed females increased both liver and gonad mass during the experiment, a result more suggestive of an 'income'-oriented spawning. Overall, prey resources before spawning appeared to influence the energy source (i.e. 'capital' or 'income') that fuelled gonadal growth by female white crappies.

In contrast to females, male white crappie gonadal production was uninfluenced by feeding treatments during the 4 months before spawning. In fact, testes mass did not differ between pre- and post-experiment fish, suggesting that testes growth is largely complete by the previous autumn, similar to spring-spawning pike Esox lucius L. (Diana \& Mackay, 1979). As with most fishes (Jonsson et al., 1991), ovaries have more energy than testes (mean in high-fed ovaries $=21.1 \mathrm{~kJ}$, in high-fed testes $=3.1 \mathrm{~kJ}$ ). Given these low energy requirements, perhaps it is not surprising that prey resources before spawning did not influence testes production. Only one study has reported males to increase testes mass in response to food (Yoneda \& Wright, 2005), and those first-time spawning Atlantic cod Gadus morhua $\mathrm{L}$. have considerably higher $I_{\mathrm{G}}$ values (4.5-7.1) than white crappie males (0.3-1.0). Even so, feeding could still influence white crappie recruitment success because male white crappies guard the embryos and yolk-sac larvae in their nests (Siefert, 1968). Thus, lower energy reserves owing to low food before spawning could reduce their ability to successfully guard their nests. 
These experimental results provide insights for managers seeking to understand variation in white crappie recruitment. First, female white crappies clearly rely on winter and spring prey to fuel ovarian growth. Exactly how much food is necessary is unknown, but the intermediate treatment reveals that consumption rates of $1-2 \%$ of body mass every 5 days is insufficient. Nonetheless, limited prey during winter and spring can limit white crappie YCS at an early stage, through limited egg production. A study involving 11 Ohio reservoirs found recruitment of age 2 year crappies [i.e. white crappies, and their congener, black crappie Pomoxis nigromaculatus (Lesueur)] to be related to both spawning stock size and chlorophyll $a$ concentrations (Bunnell et al., 2006). Of these two effects, spawning stock size explained more of the variation, but the positive effects of reservoir productivity on white crappie recruitment could be operating either through enhancing ovary production or by improving feeding opportunities for larval crappies. In turn, males that take advantage of high prey resources before spawning have higher energy stores to fuel their nest-guarding behaviour which, in turn, should increase larval survival rate in the population. Finally, the fact that starved white crappies still attempted to reproduce may explain why this species is prone to overpopulating small systems or farm ponds throughout the U.S. (Goodson, 1966; Gabelhouse, 1984). Independent of the feeding environment, white crappies appear to have evolved to take advantage of every reproductive opportunity, even at the expense of depleting their energy storage and potentially reducing the probability of future reproductive opportunities.

J. Stafford provided helpful advice in successfully transporting experimental fish. Reviews by J. Beuchel, S. Hale, J. Savino, R. Wootton and one anonymous reviewer greatly improved this manuscript. This research was funded by Federal Aid in Sport Fish Restoration Project F-69-P, administered jointly by United States Fish and Wildlife Service and Ohio Department of Natural Resources, Division of Wildlife, and the Department of Evolution, Ecology, and Organismal Biology at The Ohio State University. This article is Contribution 1397 of the USGS Great Lakes Science Center.

\section{References}

Aas, G. H., Refstie, T. \& Gjerde, B. (1991). Evaluation of milt quality of Atlantic salmon. Aquaculture 95, 125-132.

Allen, M. S. \& Miranda, L. E. (1998). An age-structured model for erratic crappie fisheries. Ecological Modelling 107, 289-303.

Beam, J. H. (1983). The effect of annual water level management on population trends of white crappie in Elk City Reservoir, Kansas. North American Journal of Fisheries Management 3, 34-40.

Bernardo, J. (1996). Maternal effects in animal ecology. American Zoologist 36, 83-105.

Bonnet, X., Bradshaw, D. \& Shine, R. (1998). Capital versus income breeding: an ectothermic perspective. Oikos 83, 333-342.

Bromley, P. J., Ravier, C. \& Witthames, P. R. (2000). The influence of feeding regime on sexual maturation, fecundity and atresia in first-time spawning turbot. Journal of Fish Biology 56, 264-278. doi: 10.1111/j.1095-8649.2000.tb02105.x

Bunnell, D. B. \& Marschall, E. A. (2003). Optimal energy allocation to ovaries after spawning. Evolutionary Ecology Research 5, 439-457.

Bunnell, D. B., Gonzalez, M. J. \& Stein, R. A. (2003). Zooplankton biomass enhances growth, but not survival, of first-feeding Pomoxis spp. larvae. Canadian Journal of Fisheries and Aquatic Sciences 60, 1314-1323.

Bunnell, D. B., Scantland, M. A. \& Stein, R. A. (2005). Testing for evidence of maternal effects among individuals and populations of white crappie. Transactions of the American Fisheries Society 134, 607-619.

Bunnell, D. B., Hale, R. S., Vanni, M. J. \& Stein, R. A. (2006). Predicting crappie recruitment in 
Ohio reservoirs with spawning stock size, larval density, and chlorophyll concentrations.

North American Journal of Fisheries Management 26, 1-12.

Burton, M. P. \& Idler, D. R. (1984). The reproductive cycle in winter flounder, Pseudopleuronectes americanus (Walbaum). Canadian Journal of Zoology 62, 2563-2567.

Chambers, R. C. \& Leggett, W. C. (1996). Maternal influences on variation in egg sizes in temperate marine fishes. American Zoologist 36, 180-196.

Colvin, M. A. \& Vasey, F. W. (1986). A method of qualitatively assessing white crappie populations in Missouri reservoirs. In Reservoir Fisheries Management: Strategies for the 80's (Hall, G. E. \& Van Den Avyle, M. J., eds), pp. 79-85, Bethesda, MD: American Fisheries Society.

Diana, J. S. \& Mackay, W. C. (1979). Timing and magnitude of energy deposition and loss in the body, liver, and gonads of northern pike (Esox lucius). Journal of the Fisheries Research Board of Canada 36, $481-487$.

Evans, J. P. \& Geffen, A. J. (1998). Male characteristics, sperm traits, and reproductive success in winter-spawning Celtic Sea Atlantic Herring, Clupea harengus. Marine Biology 132, 179-186.

Fletcher, D. A. \& Wootton, R. J. (1995). A hierarchical response to differences in ration size in the reproductive performance of female three-spined sticklebacks. Journal of Fish Biology 46, 657-668. doi: 10.1111/j.1095-8649.1995.tb01102.x

Gabelhouse, D. W. (1984). An assessment of crappie stocks in small Midwestern private impoundments. North American Journal of Fisheries Management 4, 371-384.

Gage, M. J. G., Stockley, P. \& Parker, G. A. (1995). Effects of alternative male mating strategies on characteristics of sperm production in the Atlantic salmon (Salmo salar): theoretical and empirical investigations. Philosophical Transactions of the Royal Society of London B 350, 391-399.

Goodson, L. F. (1966). Crappie. In Inland Fisheries Management (Calhoun, A., ed.), pp. 312332. Sacramento, CA: California Department of Fish and Game.

Hay, D. E. \& Brett, J. R. (1988). Maturation and fecundity of Pacific herring (Clupea harengus pallasi): an experimental study with comparisons to natural populations. Canadian Journal of Fisheries and Aquatic Sciences 45, 399-406.

Hay, D. E., Brett, J. R., Bilinski, E., Smith, D. T., Donaldson, E. M., Hunter, G. A. \& Solmie, A. V. (1988). Experimental impoundments of prespawning Pacific herring (Clupea harengus pallasi): effects of feeding and density on maturation, growth, and proximate analysis. Canadian Journal of Fisheries and Aquatic Sciences 45, 388-398.

Hayward, R. S. \& Arnold, E. (1996). Temperature dependence of maximum daily consumption in white crappie: implications for fisheries management. Transactions of the American Fisheries Society 125, 132-138.

Hirshfield, M. F. (1980). An experimental analysis of reproductive effort and cost in Japanese medaka, Oryzias latipes. Ecology 61, 282-292.

Hislop, J. R. G., Robb, A. P. \& Gauld, J. A. (1978). Observations on effects of feeding level on growth and reproduction in haddock, Melanogrammus aeglefinus (L.) in captivity. Journal of Fish Biology 13, 85-98. doi: 10.1111/j.1095-8649.1978.tb03416.x

Holmgren, K. (2003). Omitted spawning in compensatory-growing perch. Journal of Fish Biology 62, 918-927. doi: 10.1046/j.1095-8649.2003.00086.x

Jonsson, K. I. (1997). Capital and income breeding as alternative tactics of resource use in reproduction. Oikos $\mathbf{7 8}, 57-66$.

Jonsson, N., Jonsson, B. \& Hansen, L. P. (1991). Energetic cost of spawning in male and female Atlantic salmon (Salmo salar L.). Journal of Fish Biology 39, 739-744. doi: 10.1111/j.10958649.1991.tb04403.x

Jørgensen, C., Ernande, B., Fiksen, Ø. \& Dieckman, U. (2006). The logic of skipped spawning in fish. Canadian Journal of Fisheries and Aquatic Sciences 63, 200-211.

Karlsen, O., Holm, J. C. \& Kjesbu, O. S. (1995). Effects of periodic starvation on reproductive investment in first-time spawning Atlantic cod (Gadus morhua L.). Aquaculture 133, 159-170.

Kjesbu, O. S., Witthames, P. R., Solemdal, R. \& Greer Walker, M. (1998). Temporal variations in the fecundity of Arcto-Norwegian cod (Gadus morhua) in response to natural changes in food and temperature. Journal of Sea Research 40, 303-321.

Kraus, G., Muller, A., Trella, K. \& Koster, F. W. (2000). Fecundity of Baltic cod: temporal and spatial variation. Journal of Fish Biology 56, 1327-1341. doi: 10.1111/j.1095-8649.2000.tb02146.x

Lambert, Y. \& Dutil, J. (2000). Energetic consequences of reproduction in Atlantic cod (Gadus 
morhua) in relation to spawning level of somatic energy reserves. Canadian Journal of Fisheries and Aquatic Sciences 57, 815-825.

Littell, R. C., Henry, P. R. \& Ammerman, C. B. (1998). Statistical analysis of repeated measures data using SAS procedures. Journal of Animal Science 76, 1216-1231.

Ma, Y., Kjesbu, O. S. \& Jørgensen, T. (1998). Effects of ration on the maturation and fecundity in captive Atlantic herring (Clupea harengus). Canadian Journal of Fisheries and Aquatic Sciences 55, 900-908.

Maceina, M. J. (2003). Verification of the influence of hydrologic factors on crappie recruitment in Alabama reservoirs. North American Journal of Fisheries Management 23, 470-480.

Marshall, C. T., Yaragina, N. A., Lambert, Y. \& Kjesbu, O. S. (1999). Total lipid energy as a proxy for total egg production by fish stocks. Nature 402, 288-290.

McDonough, T. A. \& Buchanan, J. P. (1991). Factors affecting abundance of white crappies in Chickamauga Reservoir, Tennessee, 1970-1989. North American Journal of Fisheries Management 11, 513-524.

Parr Instrument Co. (1993). 1672 Thermometer Operating Instruction Manual: Technical Manual 283MM. Moline, IL: Parr Instrument Co.

Rideout, R. M., Burton, M. P. M. \& Rose, G. A. (2000). Observation on mass atresia and skipped spawning in northern Atlantic cod, from Smith Sound, Newfoundland. Journal of Fish Biology 57, 1429-1440. doi: 10.1111/j.1095-8649.2000.tb02222.x

Rideout, R. M., Rose, G. A. \& Burton, M. P. M. (2005). Skipped spawning in female iteroparous fishes. Fish and Fisheries 6, 50-72. doi: 10.1111/j.1467-2679.2005.00174.x

Rijnsdorp, A. D. (1990). The mechanism of energy allocation over reproduction and somatic growth in female North Sea plaice, Pleuronectes platessa L. Netherlands Journal of Sea Research 25, 279290.

Roff, D. A. (1992). The Evolution of Life Histories. New York: Chapman \& Hall.

Sammons, S. M. \& Bettoli, P. W. (1998). Larval sampling as a fisheries management tool: early detection of year-class strength. North American Journal of Fisheries Management 18, 137-143.

Scott, D. P. (1962). Effect of food quantity on fecundity of rainbow trout, Salmo gairdneri. Journal of the Fisheries Research Board of Canada 19, 715-731.

Siefert, R. E. (1968). Reproductive behavior, incubation, and mortality of eggs, and post-larval food selection in the white crappie. Transactions of the American Fisheries Society 97, 252-259.

Solemdal, P. (1997). Maternal effects - a link between the past and the future. Journal of Sea Research 37, 213-227.

Tyler, A. V. \& Dunn, R. S. (1976). Ration, growth, and measures of somatic and organ condition in relation to meal frequency in winter flounder, Pseudopleuronectes americanus, with hypotheses regarding population homeostasis. Journal of the Fisheries Research Board of Canada 33, 63-75.

Wagner, T., Hayes, D. B. \& Bremigan, M. T. (2006). Accounting for multilevel data structures in fisheries data using mixed models. Fisheries 31, 180-187.

Wootton, R. J. (1973). The effect of size of food ration on egg production in the female threespined stickleback, Gasterosteus aculeatus L. Journal of Fish Biology 5, 89-96. doi: 10.1111/j.10958649.1973.tb04433.x

Wootton, R. J. (1977). Effect of food limitation during the breeding season on the size, body components and egg production of female sticklebacks (Gasterosteus aculeatus). Journal of Animal Ecology 46, 823-834.

Yoneda, M. \& Wright, P. J. (2005). Effect of temperature and food availability on reproductive investment of first-time spawning male Atlantic cod, Gadus morhua. ICES Journal of Marine Science 62 , $1387-1393$.

Zweifel, R. D. (2000). Development and evaluation of a bioenergetics model for white crappie. Master's Thesis, University of Missouri-Columbia, Columbia, MO. 